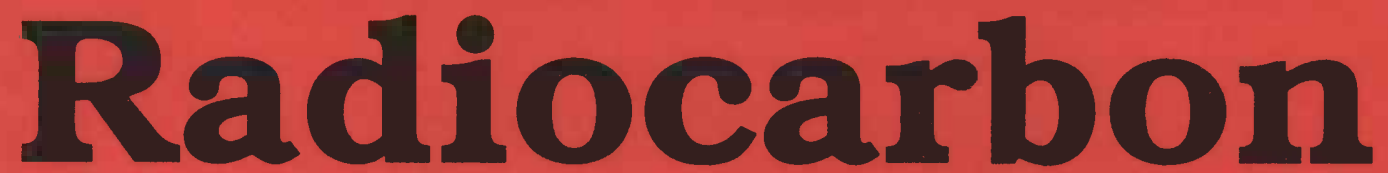

An International Journal of Cosmogenic Isotope Research

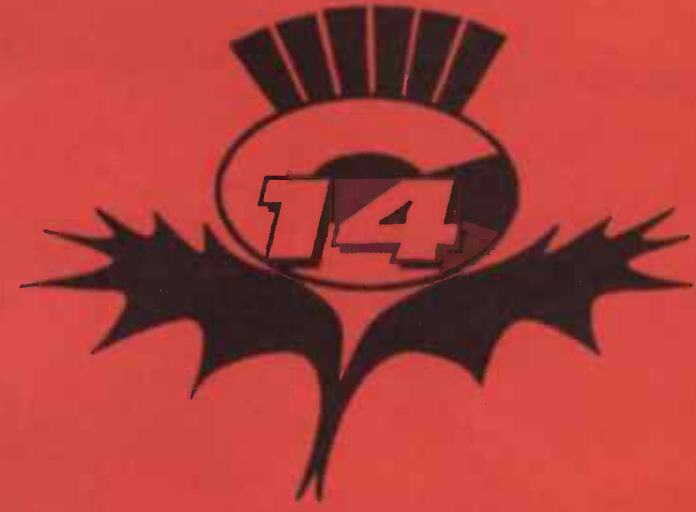

15th International

Radiocarbon Conference

Glasgow, Scotland

15-19 August 1994

\title{
Conference Editors
}

Gordon T. Cook

Douglas D. Harkness

Brian F. Miller

E. Marian Scott

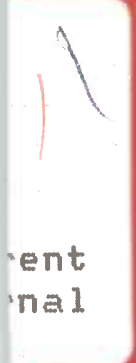

Department of Geosciences

The University of Arizona

471.7 East Ft. Lowell Road

Tucson, Arizona 85712 USA 


\title{
RADIOCARBON
}

An International Journal of Cosmogenic Isotope Research

\author{
Editor: AUSTIN LONG \\ Consulting Editor: A. J. T. JULL \\ Managing Editor: RENEE S. KRA \\ Assistant Editors: DAVID R. SEWELL, KIMBERLEY TANNER ELLIOTT \\ Published by \\ Department of Geosciènces \\ The University of Arizona
}

Published three times a year at The University of Arizuna, Tucson, AZ 85712. USA. 1996 by the Department of Geosciehces, The University of Arizona.

Subscription rate (1996): $\$ 115.00$ (for institutions), $\$ 85.00$ (for individuals), $\$ 42.50$ (for students with proper identification). Foreign pnstage is extra. A complete price lișt, including Proceedings of. Initernational Conferences, special publications and 1996 subscription categories, appears in the back of this issue. Back issues may be obtained by contacting RADIOCARBON.

All correspondence and manuscripts should be addressed to the Managing Editor, RADIOCARBON, Department of Geosciences, The University of Arizona, 4717 East Fia. Lowell Road, Tucson, AZ 85712 USA. Tel: (520) 881-0857; Fax: (520) 881-0554. (N.B.: new telephone area code!) Please note ơir e-mail addresses:

\section{INTERNET: c14@packrat.aml.arizona.edu or rkra@packrat.aml.arizona.edu}

Offprints. The minimum offprint order for each article will be 100 copies without covers. No offprints will be furnished free of charge unless page charges are paid (see below). Covers arge also available.

Page charges. For 1996, each institution sponsoring research reported in a technical paper will be asked to pay a charge of $\$ 50.00$ per printed page. This represents a $\$ 30$ reduction in price from 1.994. Institutions or authors paying such charges will be entitled to 100 free offprints without covers. No-charges will.be made if the author indicates that the 'author's institution is unable to pay, and payment of page charges for an article will, in no çase, be a condition for its acceptance.

Missing issues will be replaced without charge only if claim is made within three months (six months for India, New Zealand and Australia) after the publication dâte. Claims for missing issuess will not be honored if non-delivery results from failure by the subscriber to notify the Journal of an address change.

Illustrations should include explanation of symbols used. Copy that cannot be reproduced cannot be accepted. Whenever possible, reduce figures for direct publication. Line drawings shoüld be in black India ink on white drawing board, tracing cloth, or coordinate paper printed in blue and should be-accompanied by clear ozalids or reduced photographs for use by the reviewers. Photographs should be positive prints. Figures (photographs and line drawings) should be numbered consecutively through each article, using Arabic numerals. Tables may be accepted as camera-ready copy.

Citations. A number of radiocarbon dates appear in publications without laboratory citation or reference to published date lists. We ask authors of research articles and date lists to include proper citation (laboratory number and date-list citation) in all publications in which radiocarbon dates appear.

Radiocarbon Measurements: Comprehensive Index, 1950-1965. This index covers all published ${ }^{14} \mathrm{C}$ measurements through Volume 7 of RADIOCARBON, and incorporates revisions made by all laboratories. It is available at $\$ 35.00$ per copy.

List of laboratories. Our comprehensive list of laboratories is àvailable upon request. We are expanding the list to include additional laboratories and scientific agencies with whom we have established contacts. The editors welcome information on these or other scientific organizations. We ask all laboratory directors to provide their laboratory code designation, as well as current telephone and fax numbers, and e-mail addresses. Changes in names or addresses, additions or deletions should be reported to the Managing Editor. Conventional and AMS laboratories are now arranged in alphabetical order by country and we include laboratories listed by code designation. 


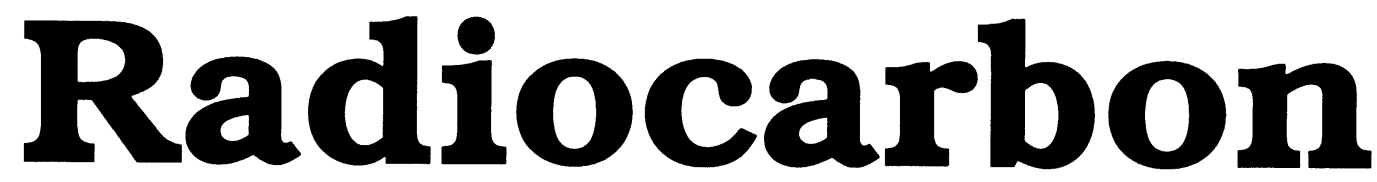

An International Journal of Cosmogenic Isotope Research

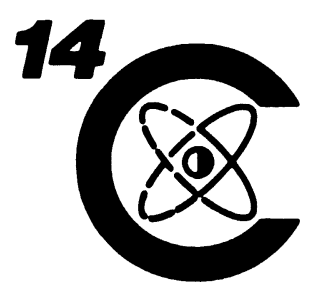

Editor

AUSTIN LONG

Consulting Editor

A. J. T. JULL

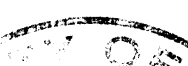

Managing Editor

RENEE S. KRA

Assistant Editors

DAVID R. SEWELL

KIMBERLEY TANNER ELLIOTT

Proceedings of the 15th International Radiocarbon Conference

Department of Geosciences

The University of Arizona

4717 East Ft. Lowell Road

Tucson, Arizona 85712 USA 


\section{CONTENTS}

ACKNOWLEDGEMENTS

\section{OBITUARY}

Mieczysław F. Pazdur

Anna Pazdur.

FOREWORD

G. T. Cook, D. D. Harkness, B. F. Miller and E. M. Scott xiii

\section{WELCOMING ADDRESS}

D. D. Harkness . . . . . . . . . . . . . . . . . . . . . . . . . . . . . . . .

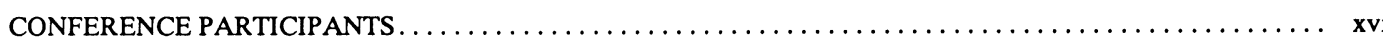

\section{I. ${ }^{14} \mathrm{C}$ IN THE RECONSTRUCTION OF PAST ENVIRONMENTS}

A. ${ }^{14} \mathrm{C}$ in Carbonates, Sediments, Shells, Tephra and Other Environmental Media

Radiocarbon Age Offsets in Different-Sized Carbonate Components of Deep-Sea Sediments John Thomson, G. T. Cook, Robert Anderson, A. B. MacKenzie, D. D. Harkness and I. N. McCave ......

Paleoclimatic Implications of Radiocarbon Dating Of Speleothems from the Cracow-Wielun Upland, Southern Poland Anna Pazdur, Mieczysław F. Pazdur, Jacek Pawlyta, Andrzej Gorny and Michat Olszewski . .

Radiocarbon and Thermoluminescence Studies of the Karst Pipe Systems in Southwest England and South Wales

Mieczystaw F. Pazdur, Andrzej Bluszcz, Anna Pazdur and Iwona Morawiecka

Radiocarbon Dating of Shells and Foraminifera from the Skagen Core, Denmark: Evidence of

Reworking

Susanne Heier-Nielsen, Keld Conradsen, Jan Heinemeier, K. L. Knudsen, H. L. Nielsen, Niels Rud and $\AA$. E. Sveinbjörnsdottir.

Radiocarbon Dating of Holocene Sediments: Flood Events and Evolution of the Labe (Elbe) River in

Central Bohemia (Czech Republic)

Pavel Jílek, Jaroslava Melková, Eliška Rủziðková, Jan Šilar and Antonín Zeman . . . . . . . . . . . 131

Radiocarbon Dating Recent Volcanic Activity on Faial Island (Azores) José Madeira, A. M. Monge Soares, António Brum Da Silveira and António Serralheiro

Radiocarbon Age of the Laacher See Tephra: 11,230 \pm 40 BP Irena Hajdas, Susan D. Ivy-Ochs, Georges Bonani, André F. Lotter, Bernd Zolitschka and Christian Schlüchter....

${ }^{14} \mathrm{C}$ Calibration in the Southern Hemisphere and the Date of the Last Taupo Eruption: Evidence from Tree-Ring Sequences

R. J. Sparks, W. H. Melhuish, J. W. A. McKee, John Ogden, J. G. Palmer and B. P. J. Molloy.

A Correction for $\mathrm{In}$-Situ ${ }^{14} \mathrm{C}$ in Antarctic Ice with ${ }^{14} \mathrm{CO}$

Job van Roijen, Klaas van der Borg, Arie de Jong and Johannes Oerlemans

Radiocarbon-Dated Subfossil Stomach Oil Deposits from Petrel Nesting Sites: Novel

Paleoenvironmental Records from Continental Antarctica Achim Hiller, Wolf-Dieter Hermichen and Ulrich Wand 


\section{xxxviii Contents}

\section{B. Past Environments}

A 30,000-Year Pollen and Radiocarbon Record from Highland Sumatra as Evidence for Climatic Change

B. K. Maloney and F. G. McCormac.

A Comparative Study of Monsoonal and Non-Monsoonal Himalayan Lakes, India Sheela Kusumgar, D. P. Agrawal, R. D. Deshpande, Rengaswamy Ramesh, Chhemendra Sharma and

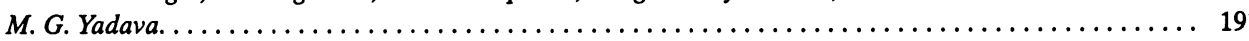

Precision Calendar-Year Dating of the Elm Decline in a Sphagnum-Peat Bog in Southern Sweden Göran Skog and Joachim Regnéll

II. ${ }^{14} \mathrm{C}$ IN ARCHAEOLOGY

\section{A. Dating of Cultures and Sites}

${ }^{14} \mathrm{C}$ Dating of an Israelite Biblical Site at Kuntillet Ajrud (Horvat Teman) Zeev Meshel, Israel Carmi and Dror Segal ...

Tell Es-Sultan (Jericho): Radiocarbon Results of Short-Lived Cereal and Multiyear Charcoal Samples From the End of the Middle Bronze Age Hendrik J. Bruins and Johannes van der Plicht. .

Berlin ${ }^{14} \mathrm{C}$ Dates of Archaeological Sites in Vietnam Jochen Görsdorf and Nguyen Viet.

Radiocarbon Dates of the Earliest Neolithic in Central Europe Harald Stäuble...

Re-Evaluation of the Neolithic in Eastern Hungary Based on Calibrated Radiocarbon Dates Ede Hertelendi, Nándor Kalicz, Pál Raczky, Ferenc Horváth, Mihály Veres, Éva Svingor, István Futó and Lászlo Bartosiewicz . .

${ }^{14} \mathrm{C}$ AMS Dating the Transition from the Paleolithic to the Neolithic in South China Sixun Yuan, Guoxing Zhou, Zhiyu Guo, Zimo Zhang, Shijun Gao, Kun Li, Jiangjun Wang, Kexing Liu,

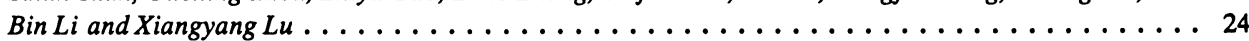

The Occupation History of the Region Between the Dvina and Lovat Rivers in Relation to the Dynamics of Environmental Change

G. I. Zaitseva, A. M. Mikliaev and A. N. Mazurkevich . .

Radiocarbon Dating of the Zagreb Upper Town Prehistoric Settlement Bogomil Obelic, Marija Šmalcelj, Nada Horvatiň̌ic, Romana Bistrović and Adela Sliepčević. . .

Evidence for a Lost Millennium in Biblical Chronology G. E. Aardsma.

B. Methodological Development

Direct Radiocarbon Dating of Pottery: Selective Heat Treatment to Retrieve Smoke-Derived Carbon Emmanuelle Delqué Kolix

Is Tooth Enamel Carbonate a Suitable Material for Radiocarbon Dating?

R. E. M. Hedges, J. A. Lee-Thorp and N. C. Tuross.

Problems in Dating Stone-Age Settlements on Sandy Soils: The Hof Ten Damme Site Near Melsele, Belgium

Mark J. Y. Van Strydonck, Jean-Pierre Van Roeyen, Guido Minnaert and Cyriel Verbruggen .

Dating Pictographs with Radiocarbon Wayne Ilger, Marian Hyman, John Southon and Marvin Rowe.

Chemical Composition and Sample Preparation of Archaeological Wood for Radiocarbon Dating

Radiocarbon Dating of Biochemically Characterized Hair

R. E. Taylor, P. E. Hare, Christine A. Prior, Donna L. Kirner, Lijun Wan and Richard R. Burky

Studies on Selected Proteins of Bone in Archaeology Harry Sobel and Rainer Berger 
A Computer-Based Database for Radiocarbon Dates of Central Andean Archaeology Adam Michczyniski, Andrzej Krzanowski, Mieczysław F. Pazdur and Mariusz S. Ziotkowski . . . . . . 337

\section{CALIBRATION OF THE ${ }^{14} \mathrm{C}$ TIME SCALE}

\section{A. Calibration Tools}

The Swedish Time Scale: A Potential Calibration Tool for the Radiocarbon Time Scale During the Late Weichselian

Barbara Wohlfarth, Svante Björck and Göran Possnert

Radiocarbon Variations from Tasmanian Conifers: Results from Three Early Holocene Logs Mike Barbetti, Trevor Bird, George Dolezal, Gillian Taylor, Roger Francey, Edward Cook

AMS ${ }^{14} \mathrm{C}$ Dating of Varved Sediments from Lake Suigetsu, Central Japan and Atmospheric ${ }^{14} \mathrm{C}$ Change During the Late Pleistocene Hiroyuki Kitagawa, Hitoshi Fukuzawa, Toshio Nakamura, Makoto Okamura, Keiji Takemura, Akira Hayashida and Yoshinori Yasuda ................................ 371

Radiocarbon Dating Tephra Layers in Britain and Iceland A. J. Dugmore, G. T. Cook, J. S. Shore, A. J. Newton, K. J. Edwards and Guðrún Larsen . .

A Comparison of Marine and Terrestrial Radiocarbon Ages from Northern Chile John R. Southon, Amy Oakland Rodman and Delbert True .

Location-Dependent Differences in the ${ }^{14} \mathrm{C}$ Content of Wood F. G. McCormac, M. G. L. Baillie, J. R. Pilcher and R. M. Kalin .

Radiocarbon Dating of Prehistoric Shell from New Zealand and Calculation of the $\Delta R$ Value Using Fish Otoliths T. F. G. Higham and A. G. Hogg. 409

Cosmogenic Radiocarbon and Cyclical Natural Processes Valentin Dergachev and Vladimir Chistyakov

\section{B. Data Analysis}

Radiocarbon Calibration and Analysis of Stratigraphy: The OxCal Program Christopher Bronk Ramsey. .

A Bayesian Approach to the Use of ${ }^{14} \mathrm{C}$ Dates in the Estimation of the Age of Peat J. A. Christen, R. S. Clymo and C. D. Litton ...

Stratified ${ }^{14} \mathrm{C}$ Dates and Ceramic Chronologies: Case Studies for the Early Bronze Age at Troy

(Turkey) and Ezero (Bulgaria)

$$
\text { Bernhard Weninger. }
$$

\section{IV. ${ }^{14} \mathrm{C}$ AS A TRACER OF THE DYNAMIC CARBON CYCLE IN THE CURRENT ENVIRONMENT}

\section{A. Impact of the Nuclear Fuel Cycle}

Anthropogenic ${ }^{14} \mathrm{C}$ Marine Geochemistry in the Vicinity of a Nuclear Fuel Reprocessing Plant G. T. Cook, F. H. Begg, Philip Naysmith, E. M. Scott and Martin McCartney ...............

Ecological Chronology of Nuclear Fuel Cycle Sites Michael Buzinny, Nikolaj Kovalyukh, Ilja Likhtarjov, Ivan Los, Valerij Nesvetajlo, Mieczystaw F. Pazdur, Vadim Skripkin, Oleg Shkvorets and Emlen Sobotovich . . . . . . . . . . . 469

${ }^{14} \mathrm{CH}_{4}$ Emissions from Nuclear Power Plants in Northwestern Europe Roos Eisma, Alex T. Vermeulen and Klaas van der Borg.

Radiocarbon Dispersion around Canadian Nuclear Facilities G. M. Milton, S. J. Kramer, R. M. Brown, C. J. W. Repta, K. J. King and R. R. Rao

Concentration of Radiocarbon and Its Chemical Forms in Gaseous Effluents, Environmental Air, Nuclear Waste and Primary Water of a Pressurized Water Reactor Power Plant in Hungary Mihály Veres, Ede Hertelendi, György Uchrin, Eszter Csaba, István Barnabás, Péter Ormai, Gabor Volent and István Futo. 
A Survey of Environmental ${ }^{14} \mathrm{C}$ Levels in Hong Kong

P. L. Leung, M. J. Stokes, S. H. Qiu and L. Z. Cai

B. Quantifying Variations

Atmospheric ${ }^{14} \mathrm{CO}_{2}$ Variations in the Equatorial Region

Kazimierz Rozanski, Ingeborg Levin, Jürgen Stock, Raul E. Guevara Falcon and Fernando Rubio . . . . .

Regional Variability of Surface Ocean Radiocarbon from Southern Great Barrier Reef Corals

Ellen R. M. Druffel and Sheila Griffin

The ${ }^{14} \mathrm{C}$ Content of Modern Vegetation Samples from the Flanks of the Katla Volcano, Southern Iceland

J. S. Shore, G. T. Cook and A. J. Dugmore.

C. Components of the Cycle

Estimating Flow and Recharge Rates of Groundwater in Western Taiwan Using Radiocarbon and Tritium

Tsung-Kwei Liu .

Radiocarbon Concentration and Origin of Thermal Karst Waters in the Region of the Bükk Mountains,

Northeastern Hungary

Ede Hertelendi, Mihály Veres, István Futo, Éva Svingor, Lajos Mikó, László Lénárt,

Jozsef Deak and Miklos Süveges. . .

Origin of ${ }^{14} \mathrm{C}$ in Icelandic Groundwater

Árný E. Sveinbjörnsdottir, Jan Heinemeier and Stefán Arnorsson.

Use of Bomb-Produced ${ }^{14} \mathrm{C}$ to Evaluate the Amount of $\mathrm{CO}_{2}$ Emanating from Two Peat Bogs in

Finland

Högne Jungner, Eloni Sonninen, Göran Possnert and Kimmo Tolonen.

Estimating Long-Term Carbon Accumulation Rates in Boreal Peatlands by Radiocarbon Dating Atte Korhola, Kimmo Tolonen, Jukka Turunen and Högne Jungner

A Method for Quantifying Deep-Sea Carbonate Dissolution Using ${ }^{14} \mathrm{C}$ Dating

S. A. van Kreveld, G. M. Ganssen, J. E. van Hinte, M. M. Melkert, S. R. Troelstra,

$K$. van der Borg and A. de Jong ...

D. Fluctuations in Tree Rings

Solar Flare Particle Effects and Seasonal Radiocarbon Variations in Tree Rings of the Northern and

Southern Hemispheres

Paolo Bartolomei, Stefano Cecchini, Stefano Cini, Menotti Galli, Roberto Gaimpieri,

Cinzia Mongardi, Teresa Nanni and Agostino Salomoni.

Radiocarbon Production by the Gamma-Ray Component of Supernova Explosions

Paul E. Damon, Dai Kaimei, Grant E. Kocharov, Irina B. Mikheeva and Alexei N. Peristykh. .

A Single-Year $\delta^{13} \mathrm{C}$ Chronology from Pinus tabulaeformis (Chinese Pine) Tree Rings at Huangling, China

Steven W. Leavitt, Liu Yu, Malcolm K. Hughes, Liu Rongmo, An Zhisheng, Graciela M. Gutierrez, Shelley R. Danzer and Shao Xuemei .

Radiocarbon Dating of Buried Trees and Climate Change in West-Central Oklahoma

Owen K. Davis, Dai Kaimei, Jeffrey S. Dean, Jim Parks and Robert M. Kalin.

\section{ADVANCES IN MEASUREMENT TECHNIQUES}

\section{A. Accelerator Techniques}

AMS ${ }^{14} \mathrm{C}$ Measurements of Dissolved Inorganic Carbon in Pore Waters from a Deep-Sea "Cold Seep"

Giant Clam Community Off Hatsushima Island, Sagami Bay, Japan

Toshiyuki Masuzawa, Hiroyuki Kitagawa, Takeshi Nakatsuka, Nobuhiko Handa and Toshio Nakamura. . . .

AMS Radiocarbon Dating of Ancient Oriental Iron Artifacts at Nagoya University

Toshio Nakamura, Masahiro Hirasawa and Kenzo Igaki

Application of AMS ${ }^{14} \mathrm{C}$ Dating to Ice Core Research

A. T. Wilson. . 
The Use of Zeolite Molecular Sieves for Trapping Low Concentrations of $\mathrm{CO}_{2}$ from Environmental Atmospheres

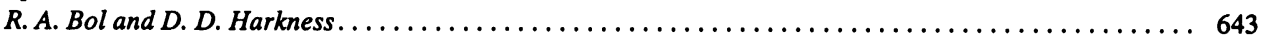

The HVEE ${ }^{14} \mathrm{C}$ System at Groningen

Andreas Gottdang, Dirk J. W. Mous and Johannes van der Plicht ................... 649

First Results from the Groningen AMS Facility

Johannes van der Plicht, Anita Aerts, Stef Wijma and Albert Zondervan

The Antares AMS Centre: A Status Report Claudio Tuniz, David Fink, Michael Hotchkis, Geraldine Jacobsen, Ewan Lawson, Andrew Smith Quan Hua, Peter Drewer, Peter Lee, Vladimir Levchenko, Roger Bird, John Boldeman, Mike Barbetti, Gillian Taylor and John Head .

Breakthrough of the Mini-Cyclotron Mass Spectrometer for ${ }^{14} \mathrm{C}$ Analysis Maobai Chen, Deming Li, Senlin Xu, Guosheng Chen, Ligong Shen, Xiangshun Lu, Weiyu Zhang, Yuexiang Zhang, Zongkun Zhong and Yingji Zhang ....

Improvements in Procedural Blanks at NOSAMS: Reflections of Improvements in Sample Preparation and Accelerator Operation A. P. McNichol, A. R. Gagnon, E. A. Osborne, D. L. Hutton, K. F. von Reden and R. J. Schneider. . . . . 683

Measurements of the Oxalic Acid II /Oxalic Acid I Ratio as a Quality Control Parameter at NOSAMS R. J. Schneider, A. P. McNichol, M. J. Nadeau and K. F. von Reden ................... 693

Reduction in Backgrounds of Microsamples for AMS ${ }^{14} \mathrm{C}$ Dating

D. L. Kirner, R. E. Taylor and John R. Southon.

Improvements and Applications of AMS Radiocarbon Measurement at Peking University Zhiyu Guo, Kexin Liu, Kun Li, Jianjun Wang, Bin Li, Xiangyang Lu, Chia-erh Chen, Tiemei Chen, Sixun Yuan and Shijun Gao ...

Radiocarbon with Gas Chromatography

Christopher Bronk Ramsey and R. E. M. Hedges.

\section{B. Advances in $\beta$ Counting}

Influence of Chromium Endowment and Surface Area of Silica-Alumina Catalysts and of Reaction Conditions on Benzene Synthesis

Peter Becker-Heidmann, Achim Hiller and Jörg Hofmann

Stability of a New, Multichannel, Low-Level Liquid Scintillation Counter System, Kvartett

Sigurour Einarsson and Pall Theodorsson.

Change of Calibration Parameters in Frequently Used Vials in Benzene Scintillation Counting Herbert Haas

Newly Designed 0.8 -ml Teflon Vial for Microvolume Radiocarbon Dating Michael Buzinny and Vadim Skripkin.

Sources of Radon Contamination in ${ }^{14} \mathrm{C}$ Dating Nada Horvatinčić, Bogomil Obelic, Ines Krajcar Bronic, Dušan Srdođ and Romana Bistrović.

External Radon Disturbance of ${ }^{14} \mathrm{C}$ Measurements in Gas-Proportional Counters Magnus Hedberg and Pall Theodorsson

C. Data Management

A Beta-Counting System Linked to a Personal Computer Kunio Omoto.

Low-Level Liquid Scintillation Counter Array with Computerized Data Acquisition and Age

Calculation Capabilities for ${ }^{14} \mathrm{C}$ Dating J. E. Noakes, J. D. Spaulding and R. J. Valenta.

A Data Acquisition System for Proportional Counters at Gliwice

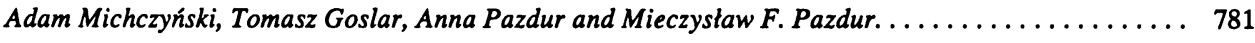

A General Computer Program for Radiocarbon Dating Laboratories Cecilio González-Gómez. 
D. Analytical Quality Control Services

Intercomparison of High-Precision $\Delta^{14} \mathrm{C}$ Analyses Using Gas Counting and AMS Ellen R. M. Druffel, Douglas J. Donahue, Sheila Griffin and George S. Burr .

Radiocarbon Age Assessment of a New, Near Background IAEA ${ }^{14} \mathrm{C}$ Quality Assurance Material A. G. Hogg, Thomas Higham, Steve Robertson, Roelf Beukens, Tuovi Kankainen, F. G. McCormac, Johannes van der Plicht and Minze Stuiver...

Radiocarbon Intercomparison Studies at the Rudjer Boškovic Institute Ines Krajcar Bronic, Nada Horvatincic, Bogomil Obelic and Romana Bristrovic . .

\section{NOTES, COMMENTS AND REPORTS}

Report of the AMS Sample Preparation Workshop, Saturday 13 August 1994

John S. Vogel

Report of the Radiocarbon in Soils Workshop, Saturday 13 August 1994

Peter Becker-Heidmann and Doug Harkness.

Report of the TIRI Workshop, Saturday 13 August 1994

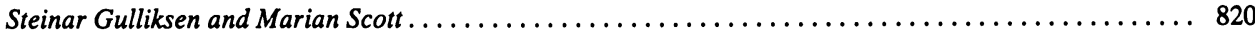

Report of the Archaeology Workshop, Sunday 14 August 1994 Mark Van Strydonck.

Report of the Carbon in Oceans Workshop, Sunday 14 August 1994 Ann P. McNichol.

Report of the Business Meeting, Friday 19 August 1994

Marian Scott, Doug Harkness and A. J. T. Jull

A Note Concerning "Location-Dependent Differences in the ${ }^{14} \mathrm{C}$ Content of Wood" by McCormac et al. Paul E. Damon

A CHRONOLOGICAL GUIDE TO INTERNATIONAL RADIOCARBON CONFERENCES AND

PUBLICATIONS

RADIOCARBON UPDATES 833

AUTHOR INDEX 835

SUBJECT INDEX 841 